\title{
Flaubert's Literary Shop in Times of "Industrial" Art
}

\author{
Christophe Ippolito \\ Amherst College
}

C Onsistent with the well-known denunciation of the common other's discourse, there

is in Flaubert a critique of the 'natural' setting of this discourse. What Baudelaire called "le lieu commun, le lieu de rencontre de la foule, le rendez-vous public de l'éloquence" 10 can take place in a specific physical space. An example of this can be found in the representation of Jules' disillusions with, first, an "assemblée philanthropique," and then, a "société de tempérance" (L'Éducation sentimentale, 1845 version, 359) -- these disillusions are similar to those of Frédéric at the Club de l'Intelligence in the second version of this book. The setting of social discourse plays an important role in the criticism and the incorporation of commonplaces in the narrative. In fact, the term 'commonplace' can be taken literally, to mean a public space in which commonplaces are regularly exchanged. In some instances, this space, or the society associated with it, is missing, and the prosaic discourse of the commonplace stops, as in the case of Homais speaking about religion: "il se tut, cherchant des yeux un public autour de lui" (Madame Bovary, 80). From "la Place des comices en elle-même" (Madame Bovary, 150) and all the discourses both public and private developed on this square ${ }^{11}$, to L'Art industriel (Arnoux's shop in L'Éducation sentimentale), and since the remarks on "l'instinct d'aller en troupeau" (Mémoires d'un fou, 238), such a space is skillfully designed by the Flaubertian narratives.

Arnoux's boutique L'Art industriel, due to its central situation in Paris and the common characteristics of the characters who visit it regularly, appears literally as a center of production of commonplaces; and these commonplaces are inserted into the text in order to create ironic effects that caricature the artist type:

L'Art industriel, posé au point central de Paris, était un lieu de rendezvous commode, un terrain neutre où les rivalités se coudoyaient familièrement. On y voyait, ce jour-là, Anténor Braive, le portraitiste des rois; Jules Burrieu, qui commençait à populariser par ses dessins les guerres d'Algérie; le caricaturiste Sombaz, le sculpteur Vourdat, d'autres encore, et aucun ne répondait aux préjugés de l'étudiant. Leurs manières 
étaient simples, leurs propos libres. Le mystique Lovarias débita un conte obscène; et l'inventeur du paysage oriental, le fameux Dittmer, portait une camisole de tricot sous son gilet, et prit l'omnibus pour s'en retourner. (L'Éducation sentimentale, 34)

In the same novel, as commonplaces are exchanged by Sénécal, Hussonnet and their friends, Cisy compares their company to a 'bad' place: "la compagnie de ces jeunes gens [était] alléchante comme un mauvais lieu et instructive comme une Sorbonne" (57). Frédéric sees Rosanette's place both as 'bad' and fascinating; it is a venue where commonplaces are constantly exchanged; they are uttered by Hussonnet, Delmar and the other guests (116-129). The same happens, although in another tone, at the Dambreuse party (156-163). Towards the end of the novel, commonplaces abound and circulate in revolutionary Paris, be it Lamartine's mot d'ordre $(297,300)$ or political statements from both sides (298-304). At the Club de l'intelligence (305-17) or at Dambreuse's funeral (374-82), commonplaces develop identically in public spaces. In the public space a conventional discourse is expected. The Club is a setting for a polyphonic discourse of political stupidity, as the funeral was the occasion for a stereotyped discourse of formal eulogies. An ideological frame - again, well represented in this novel - corresponds to these spaces. On the political side, for instance, we can find in the novel the commonplaces uttered by the party opposed to the Revolution, in favor of the principle of property (348) and the conservative values of counter-revolution (349), and against the workers's aspirations (371) and the ideas developed under the name of socialism (384-5).

Here, as in other instances, the institution of the novel as being 'memorable" ${ }^{12}$ originates to a certain extent in the fact that the novel, more than other genres, is based on a social discourse. In that discourse commonplaces appear as "pieces of the public memory." 13 The novel takes into full consideration the mnemonic power of the commonplace and its effect on the reader, and transforms the resistance (to change) that is proper to the commonplace into an asset, by incorporating it into the narrative, as a vector of 'memorability' that transfers the preconstructed over to a narrative program which will be modified over the course of the narrative. Incidentally, this shows that denouncing Flaubert as a realist would amount to mistaking the means for the end. Thus, commonplaces are not only a projection of imported discourse; their organization in Flaubert is the sign of particular ways of conceiving the preconstructed, and eventually new modes of reading: "[le] constat de la contrainte et du figement du signe définit un perspectivisme de la lecture qui est levée de toutes les censures et de l'aliénation dans la médiation linguistique," as writes Jean Bessière. ${ }^{14}$ In this perspective, commonplaces are part of a process of inventio directed against certain professional 'enemies' - such enemies as could be found in the press or in publishing houses, those 'legions' of 'industrial art' commanded by stereotypying and social conventions - who regularly overlook or suppress the purely literary aspects of novelistic representation for economic or ideological reasons. 
At the time Flaubert wrote, the term 'industrial literature' was often used to describe that which was too explicit in literature and was destined first and foremost for a first linear reading. This expression, which was used to name Arnoux's shop in L'Éducation sentimentale, is apparently derived from the title of Sainte-Beuve's famous article, "De la littérature industrielle," which was published in the Revue des Deux Mondes in 1839. In this article, Sainte-Beuve denounces, among other things, the adverse effect of advertisement on independent criticism. According to him, this is a manifestation of the fact that literature, at the time of the industrial Revolution in France, becomes sometimes a trade more than an art. Sainte-Beuve begins by relativizing the novelty of this phenomenon: "De tout temps la littérature industrielle a existé. Depuis qu'on imprime une oeuvre, on a écrit pour vivre, et la majeure partie des livres imprimés est due sans doute à ce mobile si respectable." 15 But this is, in fact, a rhetorical beginning, as he immediately adds:

Mais, en général, la dignité des lettres subsistait, recouvrait toute cette partie matérielle secondaire [...]. [...] aujourd'hui que la littérature purement industrielle s'affiche crûment, [ce] qui la caractérise en ce moment cette littérature, et la rend un phénomène tout à fait propre à ce temps-ci, c'est la naïveté et souvent l'audace de sa requête, d'être nécessiteuse et de passer en demande toutes les bornes du nécessaire [...]; c'est de se rencontrer là où on la supposerait et où on l'excuse le moins, dans les branches les plus fleuries de l'imagination, dans celles qui sembleraient tenir aux parties les plus délicates et les plus fines du talent. [...] l'industrie pénètre dans le rêve et le fait à son image, tout en se faisant fantastique comme lui [...]. La littérature industrielle est arrivée à supprimer le critique [...] (181-183).

Thus, he stigmatizes the fact that this literature has transgressed too many borders: the essential, the respect for 'true' literature, and the respect for the critic's role. Insofar as an independent criticism no longer exists, interpretation becomes partial or deformed for professional and/or commercial reasons, as is the case with a kind of literary critic particularly targeted in Flaubert's Correspondance. The following remark gives an idea of the esteem in which Flaubert held some literary critics: "Chacun des arts a sa lèpre particulière, son ignominie mortelle qui lui ronge le visage. La peinture a le portrait de famille, la musique a la romance, la littérature a le critique et l'architecture a l'architecte."16 Opposed here are arts and their counterparts destined for mass consumerism (portrait de famille, romance), which are designed by professionals living off their art (thus the exact opposite of the "write so as not to live" motto). These professionals consider their art as a trade, and do not consider it as "art pour art." In the critic's case, an explanation of this 
judgement can be found in the lack of independent criticism of which Sainte-Beuve had witnessed the development. He had analysed the causes of this phenomenon in describing the industrial support of 'industrial' literature, i.e. a new way of advertising:

Les conséquences de l'annonce furent rapides et infinies. On eut beau vouloir séparer dans le journal ce qui restait consciencieux et libre, de ce qui devenait public et vénal: la limite du filet fut bientôt franchie. La réclame servit de pont (ibid., 190).

C'est à la littérature imprimée, à celle d'imagination particulièrement, aux livres auparavant susceptibles de vogue, et de degré en degré à tous les ouvrages nouveaux, que le mal, dans la forme que nous dénonçons, s'est profondément attaqué (ibid., 194).

Flaubert takes a similar stance, when asked by Charpentier to lend his name to a prospectus réclame issued to advertise the upcoming publication of the review La Vie Moderne:

Bien que je n'aime pas ça, mettez mon nom sur votre papier, puisque ça peut vous être utile. Mais vous êtes le premier à qui j'accorde cette permission, et serez le seul probablement. ${ }^{17}$

As an example of industrial literature, Sainte-Beuve selects the serial novel:

Avec nos moeurs électorales, industrielles, tout le monde, une fois au moins dans sa vie, aura eu sa page, son discours, son prospectus, son toast, sera auteur. De là à faire un feuilleton, il n'y a qu'un pas. Pourquoi pas moi aussi? se dit chacun (ibid., 188).

Il y a des auteurs qui n'écrivent plus leurs romans de feuilletons qu'en dialogue, parce qu'à chaque phrase, et quelquefois à chaque mot, il y a du blanc, et que l'on gagne une ligne". (ibid., 195).

How is 'industrial literature' represented in Flaubert, if not by the likes of physiologies i.e. brief descriptions of social types ${ }^{18}$-, melodrama, and low quality novels, often appearing as feuilletons $?^{19}$ Flaubert was so infuriated over the low-quality feuilletons that his writing became in many ways focused on one problem: how to write a text that could never be compared to a conventional and insipid roman-feuilleton playing on all kinds of suspense. The importance of his initial hostile reaction to this kind of literature, as opposed to the "poésie pure"20 and the doctrine of "l'Art pour l'art," is demonstrated by numerous attacks in the Correspondance against what Flaubert viewed as sub-literature: 
Quelle bonne balle que ce Dumas! [...] Mais quel dommage qu'une aussi belle organisation soit tombée si bas! La mécanique! la mécanique! faire au meilleur marché possible le plus possible pour le plus grand nombre de consommateurs. On ne le lisait pas tant quand il faisait Angèle. Tout le monde le lit maintenant par la raison qu'on boit plus habituellement du Médoc ordinaire que du Laffitte. On a beau dire, il y a jusque dans les arts des popularités honteuses. La sienne est du nombre. ${ }^{21}$

Analyzing in Flaubert the opposition of the representations of art with industry - of which this marketing towards a reader taken as mass consumer ("tout le monde") belongs implies raising questions about genres good enough for a first linear reading, but not for a literary one; genres not necessary, in Sainte-Beuve's opinion; genres not to be read, genres against which Flaubert would advise Mlle Leroyer de Chantepie. This opposition also implies raising questions about the relations between copying, mimesis, and reading, and indeed, the renewal of mnemotechnic practices in general. Historically, the simultaneous development at the time Flaubert wrote of the opposed doctrines of "l'Art pour l'Art" (Flaubert's position ${ }^{22}$ ) on the one hand, and of utilitarian art on the other, takes place at a time in which, as Sartre said, "[une] littérature bourgeoise, antiromantique s' installe avec Ponsard, Augier, Jules Sandeau;" this is a time, then, for "la moralité dans l'art," but also for "l'art social, de progrès," 23 with Pierre Leroux, Fourtoul, Sand, Louis Blanc, and in some aspects Hugo, ${ }^{24}$ after Sue and Lamartine. These oppositions are founded on two diametrically antithetic conceptions of the beautiful: on the one hand, then, are included Flaubert ("Le Beau est ce qui m'excite vaguement") and the Goncourt ("Le Beau, disent les Goncourt, est ce que votre maîtresse et votre servante trouvent d'instinct affreux;" cf. Sartre $3: 203$, for both quotations); on the other, partisans of an utilitarian art. Outside of this opposition stand 'industrial' texts to which no value at all can be attributed; according to Flaubert, they lack Beauty and have one central component: they are as ephemeral as newspapers. ${ }^{25}$ But the fact is that industrial literature, among other ways of advertising itself, may present its case by using the doctrine of utilitarian art as an alibi.

When this 'sub-literature' is described in greater detail, the critique is even more vehement. Flaubert, after an homage to Chateaubriand at his future grave in Saint-Malo, and before a lengthy description of ugly prints at Cancale, echoes Sainte-Beuve's preoccupations when he deplores the progression of 'industrial literature':

Le tailleur est le roi du siècle, la feuille de vigne en est le symbole [...].

[Le public] se ruera sur la gravure et laissera le tableau, chantera la romance et dormira à Beethoven, saura tout Béranger par coeur et pas un vers d'Hugo. [...]

Les mets communs lui vont vite, et demain, encore du Scribe, du Vernet, de l'Eugène Sue, quelque chose de digestion facile et qui ne tienne pas de 
place au ventre pour qu'on puisse en manger davantage. L'homme des champs particulièrement se délecte dans le mauvais avec une ténacité édifiante. Son mauvais à lui est plus sincèrement sot, plus sauvagement bête; il y met moins de finesse que le citadin qui au moins change de modes s'il ne change pas de goût. A combien de milliers d'exemplaires se vendent actuellement dans les campagnes l'Amour conjugal et Faublas ! (Par les champs et par les grèves, 540)

The metaphor of digestion opposes here the 'easily' digested 'industrial texts' and those which make for a 'slow digestion,' a ruminatio. As for Béranger's texts, they are continuously mocked as an example of 'industrial texts,' and his "traits de la satire" (his predictable discourse against religion) are ridiculed. ${ }^{26}$ On the notion of fashion, I would simply like to point out the recurrence in the above text and in Madame Bovary of an underlying and undermined discourse on fashion and the ephemeral. Undermined indeed, since according to provincial habits, fashion is imposed on a passive audience. Fashion is something to be copied par excellence, and as such, it may be linked to a preliminary reading. As for some occurrences in Madame Bovary: "d'après des dessins de mode qu'elle emprunta" (26); "des robes à la façon de la ville" (27). And as we have seen, it is not a mere coincidence if Homais repeats Léon's advice for a name to be given to Emma's baby. They should call her "Madeleine, qui est excessivement à la mode maintenant" (91). But again, this name would best characterize Emma herself, as Emma is a kind of Madeleine, an abortive copy of Madeleine, and her story a variant of the myth of Madeleine, which becomes popular again in the second half of the nineteenth century, after having fallen into oblivion for close to a hundred years. Fashion is here imposed on the caricatured provincial characters in a way similar to that in which the ephemeral 'bad' books are imposed on passive readers.

Thus, 'bad' books, ${ }^{27}$ in Sartrian terms, are to be contrasted with those that present a "donné [...] travaillé de telle sorte qu'il puisse être librement créé par la lecture" (3: 323). 'Bad' books, then, could be compared to the stories of the Queen of Sheba, who says to Antoine: "je sais une foule d'histoires à raconter, toutes plus divertissantes les unes que les autres." 28 At one point, the Queen begins to tell such a story:

C'était une nuit que le roi Salomon perdait la tête. Enfin nous conclûmes un marché. Il se leva, et sortant à pas de loup...

Elle fait une pirouette.

$\mathrm{Ah}$ ! ah! bel ermite! tu ne le sauras pas! tu ne le sauras pas! (ibid., 532)

This abortive incipit is a Pascalian divertissement, and thus a temptation, meant to divert Antoine from his meditation; it is rhetorically arranged to seduce her auditor, because of its ingredients (famous characters, sex), but above all because it plays on suspense, like the 
stories of The Thousand and One Nights, by raising delayed questions (why is Solomon mad, why is he acting like that...?) that will, in this case, never be answered since the tale is brutally interrupted, in a process which could be compared to the way the serial novel is presented in newspapers (delayed questions that will be answered, but in the next issue of the newspaper).

What are the counter-indicated books or publications more particularly mentioned in Flaubert's works? Proscribed are, besides serial novels, physiologies, newspapers, keepsakes ${ }^{29}$ religious booklets, albums, or almanacs. A passage from the first Éducation sentimentale offers a sample of some of the above: "Alvarès aussi aimait de plus en plus Mlle Aglaé; il avait extrait des keepsakes beaucoup de pièces de vers sur la chute des feuilles, sur un baiser, sur la rêverie, sur les cheveux, et il les copiait dans un bel album tout neuf. [...] M. Renaud lisait les Débats; on ne disait rien. [...] M. Renaud sommeillait dans son fauteuil, Mendès lisait le feuilleton" (293). All the above belong more to the ephemeral than to the memory that readers would have of literary texts. It is as if 'bad' publications were a kind of 'repoussoir' against which $L$ 'Éducation sentimentale is constructed. This starts at Arnoux's shop, where "[les] hautes glaces transparentes offraient aux regards, dans une disposition habile, des statuettes, des dessins, des gravures, des catalogues, des numéros de l'Art industriel; et les prix de l'abonnement étaient répétés sur la porte, que décoraient, à son milieu, les initiales de l'éditeur" (21). The shop's guests include Cisy who wonders why Frédéric's library does not include new and trendy forms of 'índustrial art': "Et M. de Cisy, qui s'occupait de littérature, s'étonna de ne pas voir sur la table de Frédéric quelquesunes de ces physiologies nouvelles, physiologie du fumeur, du pêcheur à la ligne, de l'employé de barrière" (142). What about the readers of the newspapers? In the travel narratives, as a proof of "abrutissement" in a factory, and since "il faut essentiellement s'instruire en voyage", the narrator notices that after their work, the children have to go to school: "aux plus avancés, on lit le Journal des Connaissances utiles." 30 This is in keeping, beyond the denunciation of the vacuousness of newspapers, with a more general stance on the institutionalized transmission of information and knowledge that Flaubert planned to criticize in Bouvard et Pécuchet's last chapter : "Je veux montrer que l'éducation, quelle qu'elle soit, ne signifie pas grand'chose, et que la nature fait tout ou presque tout." ${ }^{31}$ Two 'politically correct' newspapers, very dissimilar both in style and content (the first one being more academic, the second one more popular) are explicitly designated to the

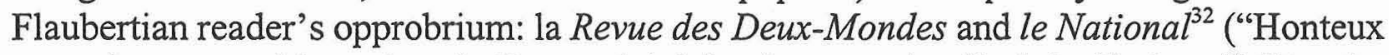
reste des superstitions dont la France éclairée s'est purgée, dirait le National" [Par les champs et par les grèves, 497]). As for the former, it is described as one of the evanescent signs of the ephemeral:

Comme ce qui est beau sera laid, comme ce qui est gracieux paraîtra sot, comme ce qui est riche semblera pauvre, nos délicieux boudoirs, nos charmants salons, nos ravissants costumes, nos intéressants feuilletons, nos 
drames palpitants, nos livres sérieux, oh! oh! comme on nous fourrera au grenier, comme on en fera de la bourre, du papier, du fumier, de l'engrais! O postérité! n'oublie pas surtout nos parloirs gothiques, nos ameublements renaissance, les discours de $\mathrm{M}$. Pasquier, la forme de nos chapeaux et l'esthétique de la Revue des Deux-Mondes (Par les champs et par les grèves, 489).

This hyperbolic dramatization of the discourse of fashion within the old topos of Ecclesiastes, "Vanitas vanitatis and omnia vanitas," is a parodic rewriting of religious discourse, designed by definition to express eternity. It is here subverted to mock the signs of the ephemeral. It is no coincidence if one of the most curious examples of industrial literature mentioned in Flaubert are the booklets on religious subjects which were distributed at the time. As Emma goes through a 'religious' crisis, Bournisien orders some (but the way she reads them does not, as is to be expected, bring the answers needed):

[...] il écrivit à M. Boulard, libraire de Monseigneur, de lui envoyer quelque chose de fameux pour une personne du sexe, qui était pleine d'esprit. Le libraire, avec autant d'indifférence que s'il eût expédié de la quincaillerie à des nègres, vous emballa pêle-mêle tout ce qui avait cours pour lors dans le négoce des livres pieux. C'étaient de petits manuels par demandes et réponses, des pamphlets d'un ton rogue dans la manière de $\mathrm{M}$. de Maistre, et des espèces de romans à cartonnage rose et à style douceâtre, fabriqués par des séminaristes troubadours ou des bas bleus repentis. Il y avait le Pensez-y bien: L'Homme du monde aux pieds de Marie, par M. de ***, décoré de plusieurs ordres; des erreurs de Voltaire, à l'usage des jeunes gens, etc. (Madame Bovary, 219-20).

Flaubert's choice here is not a surprise, insofar as we are aware of his attacks on the institution of religion. But beyond that choice, the text points out a characteristic of the first linear reading shared as much by the "lecteurs du Tableau de l'amour conjugal et du Portier des Chartreux" ${ }^{\prime 33}$ as by the readers of the religious booklets parodied above. This characteristic points out a division, a separation, and a rift between a literature defined by an aesthetic specificity - the common definition of literature in French since the end of the eighteenth century - and a literariness founded on an autonomy of the text, as opposed to other forms of texts that are industrially distributed, as Matthieu Laensberg, an 'almanach de colportage', to Berthe's nurse (Madame Bovary, 95).

More specific to the travels is the unavoidable album ${ }^{34}$ that is generally another short dictionary for received ideas. In the travels, we see the narrator copying from an album some of the 'valuable' thoughts of the visitors about a famous place, Gaube lake in Southwestern France. These reflections, a collection of received ideas, can be contrasted 
with what Chateaubriand said about those places, and this is explicitly the case here. ${ }^{35}$ In the incipit of L'Éducation sentimentale, where Frédéric returns from Paris, he is holding an album in a Romantic pose, and all the expectations of a Romantic character are put into place: "Un jeune homme de dix-huit ans, à longs cheveux et qui tenait un album sous son bras, restait auprès du gouvernail, immobile. A travers le brouillard, il contemplait des clochers [...]" (3). Christopher Prendergast demonstrates how this posture ("tenir un album") is presented as the sign of a certain Romantic sensibility in Frédéric and corresponds to a well-known cultural model of the Romantic doxa originating in literature. ${ }^{36}$ Such a discourse is precisely a target of Flaubert's irony. Here both Frédéric and a particular type of reader are ridiculed, the former as a 'Romantic hero' willing to succeed but bound to fail, and the latter as somebody falling into the trap of identification with this 'hero.' The reader should recognize that returning from Paris instead of going to Paris is, in itself, the reverse movement of the one normally made by the ambitious and successful Balzacian type, so common in Novels of Apprenticeship (the subtitle of the novel is "Histoire d'un jeune homme"). As Prendergast puts it,
[...] the sentences play ambiguously on different levels of readerly 'recognition'. A 'naive' reader will (mis-)recognise and possibly identify with, a literary stereotype; his attitude to the hero will parallel the hero's attitude to his own literal models, and will thus be caught in the same trap of taking a purely textual construction for reality. A 'clever' reader will recognise the models as stereotypes, take the requisite distance from them" (ibid.).

Thus, the album is shown to be a sign of a stereotyped Romantic discourse conveyed by 'industrial' literature. Note that Flaubert is the author of a parodied album, L'Album de la Marquise. It is a text that collects conventional, empty compliments about a woman; all are examples of bad style. A sample: "M. Alexandre Dumas fils. De fins sourcils nets et réguliers comme l'arche d'un pont." texts represented in Flaubert share (or play on, as in the two last instances) a common flaw of predictability.

But isn't this predictability an avatar of the use of industrial techniques? Industrial art was characterized by new technical procedures all linked to reproduction. ${ }^{38}$ The telegraph, "la grimace fantastique du monde moderne" (Par les champs et par les grèves, 484), was its emblem. ${ }^{39}$ From the start of the novel, Arnoux illustrates industrial art, through the name of his shop and journal, as well as through his procedures in art dealing: reproducing lithographs, and having the artist copy a painting ( $L^{\prime}$ Éducation sentimentale, 39-40). Arnoux's porcelain factory appears as an allegory of industrial art embedded in the novel: "Il fabriquait maintenant des lettres d'enseigne, des étiquettes à vin; mais son intelligence n'était pas assez haute pour atteindre jusqu'à l'Art [...]" (196). Thus, Arnoux's enterprise 
comes to symbolize the failure of reproduction, and the 'industrial' art he represents here may be a sign of a more profound concern with mimesis throughout Flaubert's narratives. The relentless effort - particularly represented in L'Éducation sentimentale — to reproduce mere copies of prestigious originals, and more generally, the anxiety about copying as a menace to the implicit, challenge the old mimesis.

\section{Notes}

${ }^{1}$ Baudelaire, "M. Gustave Flaubert, 'Madame Bovary'et 'la Tentation de saint Antoine' (L'Artiste, 18 octobre 1857). In Henri Lemaître ed., Curiosités esthétiques/L'Art romantique et autres Oeuvres critiques de Baudelaire, 644.

2 Madame Bovary, 144-152; Emma states on this square that one should "suivre un peu l'opinion du monde" (Madame Bovary, 148). There are, incidentally, "comices agricoles" in other novels as well (L'Éducation sentimentale, 388; Bouvard et Pécuchet, 210); see Jeanne Goldin, Les Comices agricoles de Gustave Flaubert..., on the subject.

${ }^{3}$ This is evident in the travel narratives in the following statement which would confirm, if necessary, the success of Madame Bovary (Flaubert meets people who know about his novel): "Ils connaissent la Bovary" (Voyage à Carthage, 708).

${ }^{4}$ Mary Carruthers, The Book of Memory. A Study of Memory in Medieval Culture. 180.

5 In "Sartre lecteur," in Michel Picard ed., La Lecture littéraire, 99.

6 Sainte-Beuve, "De la littérature industrielle" [1839], in Sainte-Beuve, Choisir les meilleurs textes, André Thérive ed., 180.

7 Par les champs et par les grèves, 544.

8 Correspondance, Huitième série, 211.

${ }^{9}$ On physiologies, see Ruth Amossy and Elisheva Rosen, Les Discours du cliché, 57, and Fritz Nies, Genres Mineurs: Texte zur Theorie und Geschichte nichtkanonischer Literatur, 111-112.

\section{Works Cited}

Amossy, Ruth and Rosen, Elisheva. Les Discours du cliché. Paris: SEDES, 1982.

Baudelaire, Charles. 'M. Gustave Flaubert, 'Madame Bovary'et 'la Tentation de saint Antoine'. L'Artiste, 18 octobre 1857. Curiosités esthétiques/L'Art romantique et autres

Oeuvres critiques de Baudelaire. Ed. Henri Lemaître. Paris: Garnier, 1962. 647-651. Carruthers, Mary J. The Book of Memory. A Study of Memory in Medieval Culture. 
Cambridge: Cambridge University Press, 1990.

Diderot, Denis. Lettre sur le commerce de la librairie [1763]. J. Proust, Ed. Paris: Editions sociales, 1964.

Flaubert, Gustave. Oeuvres complètes. Ed. Bernard Masson. L'Intégrale. 2 vols. Paris:

Seuil, 1964. In Vol. I: Novembre, L'Éducation sentimentale (1845 version), La Tentation de saint Antoine (I, II, III). In Vol. II: Bouvard et Pécuchet, Voyage aux Pyrénées et en Corse, Par les champs et par les grèves, Voyage en Orient, Voyage à Carthage.

. Madame Bovary. Moeurs de Province. Ed. Claudine Gothot-Mersch. 1971.

Classiques Garnier. Paris: Bordas, 1990.

. L'Éducation sentimentale. Histoire d'un jeune homme. Ed. Peter Michael Wetherill.

Paris: Garnier, 1984.

. L'Album de la Marquise, in Bouvard et Pécuchet, Claudine Gothot-Mersch ed., collection 'Folio'. Paris: Gallimard, 1979.

. Correspondance. Ed. Jean Bruneau. 'Pléiade'. 4 vols. published. Paris: Gallimard, 1973-. Vols. I (1973), II (1980), III (1991) \& IV (1998).

. Correspondance. Huitième série. Paris: Conard, 1930.

Gleize, Joëlle. Le double miroir. Le livre dans les livres de Stendhal à Proust. Paris: Hachette, 1992.

Goldin, Jeanne. Les Comices agricoles de Gustave Flaubert: transcription intégrale et genèse dans le manuscrit $g$ 223. Genève: Droz, 1984.

Hamon, Philippe. Texte et idéologie. Valeurs, hiérarchies et évaluations dans l'oeuvre littéraire. Paris: P.U.F., 1984.

Hugo, Victor. Les Misérables. Ed. Marius-François Guyard. 2 vols. Paris: Garnier Frères, 1963.

Lough, John. Writer and Public in France. Oxford: Clarendon Press, 1978.

Neuschäfer, H.-J., Fritz-El Ahmad, D. \& Walter, K.-P. Der Französische Feuilletonroman.

Darmstadt: Wissenschaftliche Buchgesellschaft, 1986.

Nies, Fritz. Genres Mineurs: Texte zur Theorie und Geschichtenichtkanonischer Literatur. Munich: Wilhelm Fink, 1978.

Paulhan, Jean. Les Fleurs de Tarbes. Paris: Gallimard, 1941.

Picard, Michel ed. La Lecture littéraire (Actes du Colloque tenu à Reims, 1984). Paris: Ed. Clancier-Guenaud, 1987.

Prendergast, Christopher. The Order of Mimesis. Balzac, Stendhal, Nerval, Flaubert Cambridge: Cambridge University Press, 1986.

Queneau, Raymond. Les Fleurs bleues. Paris: Gallimard, 'Folio,' 1965.

Thérive, André, ed. Sainte-Beuve. Choisir les meilleurs textes. Paris: Desclée de Brouwer, 1936.

Sartre, Jean-Paul. L'Idiot de la famille [1971-1972]. Nouvelle édition revue et complétée. 3 vols. Paris:Gallimard, 1988. 